\title{
Ten Years On: What Have We Learned? What Have We Done? What Must We Do?
}

\section{Robert Hockett*}

Ten years after the financial dramas of Autumn 2008, I take stock of what we have learned, what we have done, and what we have yet to do if we would avoid a repeat performance. The primary lessons I draw are that income and wealth distribution, the endogeneity of credit-money, and finance system structure all matter profoundly not only where justice, but also where systemic stability is concerned. The longer-term tasks still before us include a much broader and financially engineered diffusion of capital ownership over our population, citizen central banking, a permanent national investment authority, continuous public open labor market operations, debt-free or lowdebt education and health insurance, and an updated form of segregating capital-raising primary from asset-trading secondary markets in the financial sector. Shorter-term tasks include debt-forgiveness, a restoration of labor rights and countercyclical progressive taxation, and restored citizenownership of our secondary market makers in home mortgage and higher education debt. These measures will restore the nation to its erstwhile status as a productive middle class 'yeoman republic,' and in so doing will restore both justice and efficiency to our social and economic arrangements.

\section{Introduction}

Crises occasion reflection, and complex crises invite complex reflections. The financial dramas of 2008 and their sequel have been no exception. Countless words have been spoken and written about just 'what went wrong' in the lead-up and follow-up to that fateful autumn one decade ago, with many distinct causes and culprits all implicated. A ten-year anniversary, however, affords fitting occasion to sift through the multiple stories in search of a single encompassing narrative. A story that ties all altogether, if plausible, can yield a 'grade card' and 'game plan' alike - a measure by which to assess where we are and, ideally, where we must go.

I believe we can distill from the past decade's post-crisis soul-searching three broadly inclusive and mutually reinforcing lessons. In a way, these are things we learned ages ago and should never have forgotten. But forget them we did, setting the stage for '08, and going forward we must resolve not to forget them again. This will be difficult, as the lessons are already now fading from memory

Edward Cornell Professor of Law, Cornell University; Senior Counsel, Westwood Capital; Founding Board Member, Digital Fiat Currency Institute; formerly Federal Reserve Bank of New York and International Monetary Fund. 
again. More difficult still will be acting on what we have learned. For we've done very little as is, and are apt to do less now as urgency dissipates and false narratives resume their old flow.

Progressives, I believe, bear a special responsibility against this backdrop. We as a movement were skeptical already of most of the truisms the lessons I'll sketch showed are false. We are also correspondingly unwilling to forget - or to roll back the few sensible post-crisis measures our polity has taken. Keeping clear on 'the true story' of '08 should accordingly come easy for us. That is a blessing. For it is by reference to this story that we shall not only preserve what little postcrisis progress has been made, but also push forward on far more far-reaching reforms of the kind we shall need to avert coming cataclysm.

In the following pages, then, I will first briefly narrate the crisis, then carefully elaborate its three complementary lessons. Those are that income- and wealth distribution, the credit/debt nature of money, and finance's systemic structure all matter profoundly to economic justice, stability, and sustainability. Then I will note what we've done, and what still needs doing, in light of those lessons. In the end I will try to conclude both on a 'positive' and on a hortatory note. There is not only much that we must do, I conclude, but also a great deal we can do.

\section{8: What Actually Happened?}

To appreciate fully what happened in both the lead-up and sequel to 2008, one must look briefly back further - specifically, to the economy we built after the last major crash back in 1929. As I and others have shown extensively in prior work, that crash was more like the one we saw eighty years later than most seem to realize.

As in '08, so in '29 it was paired stock and real estate bubbles that burst. Also as in our more recent crash, so in the earlier one had both income and wealth been flowing to and concentrating at the top of the distribution for years. And so, correspondingly, had the financial 'services' industry developed newfangled financial instruments aimed at simultaneously enabling the increasingly wealthy to 'invest' in new ways, and the non-wealthy to borrow - from the wealthy - in new ways. These instruments quickly became the objects of speculative interest, then frenzy, among those with enough surplus or access to 'leverage' to gamble. And once their bubble had burst, tens of millions of American farmers, laborers, and homeowners were left 'underwater' - owing much more than they owned.

As I and others have empirically demonstrated, it was this private debt overhang, not any public side borrowing or other dysfunction, that lay at the root of the lengthy self-worsening slump that commenced after the crash. Millions of households with negative net worth simply no longer could spend, 'Roaring 20s' style, on the things people are paid to produce and supply. That brought on layoffs, 
further insolvencies and spending contractions, then yet more layoffs, and so on. Scarce wonder that unemployment reached heights never yet seen theretofore or since - in the '30s.

The architects of the New Deal understood both the debt-deflationary basis and the largely demand-side causal character of the slump of the '30s. They also understood the role that finance plays in connection with both. The emergency measures they took, and the longer-term structural changes they made, all reflected this deep understanding.

Massive write-downs on mortgage and other debts, along with sustained massive stimulus spending, were the core short-term strategies pursued by the New Deal. Longer-term measures targeted employee bargaining power through strengthened labor rights legislation, wealth and income inequality through tax legislation, and publicly channeled non-speculative credit availability for homeowners and small businesses through such new public lending instrumentalities as the Federal Housing Administration (FHA), the Federal National Mortgage Association (FNMA), the Reconstruction Finance Corporation (RFC), and the Small Business Administration (SBA). These latter entities, in effect, 'socialized' the most systemically important subsectors of our financial sector.

At the same time, a raft of new banking, securities, and public utility legislation maintained stability in those sectors of the financial system that had not been 'socialized.' This legislation was predicated on a new appreciation of two facts: first, that financial fraud and chicanery are stability issues as much as they are fairness issues. And second, that credit-money is endogenously generated in a modern financial system, growing in supply to accommodate and fuel asset price bubbles while evaporating as quickly during a bust. The institutions and regulations put in place under the New Deal accordingly tended either (a) to supplement or replace dysfunctional private sector institutions with more effective public institutions, (b) to operate counter-cyclically alongside private institutions in 'market-contrarian' fashion, or (c) to regulate private institutions as de facto public utilities.

During its New Deal hay day the publicly operated RFC, for example, became the largest financial institution in the world. Its balance sheet dwarfed those of Wall Street institutions. It functioned as a 'public option' for investment banking that outperformed all then-available 'private options.' FHA and FNMA, for their part, rectified 'missing markets' for mortgage insurance and secondary market-making, in so doing converting us from a nation in which fewer than $39 \%$ of households owned their own homes to one in which over $65 \%$ did. And SBA financed the founding of millions of 'startup' firms, many of which are still with us to. These were all 'public options' designed to channel credit-money stably to where it was needed for real production, and where it had previously been privately over- or under-provided in 'bipolar' fashion. The Federal Reserve, for its part, began explicitly to take on the identity of a systemic money-modulator, 
acting 'countercyclically to siphon-off excess credit-money when it was being endogenously over-supplied, and to inject it when it was endogenously contrating.

The combined effect of these legislative and public institutional innovations was a much more equitable and stable system of public credit-provision. Here was the essential public institutional foundation for what later came to be called 'the Great Moderation' experienced by the American economy.

While the New Deal arrested and reversed the nation's slump and laid a foundation for renewed and sustainable, widely shared prosperity, the outbreak of the Second World War set the economy onto a particularly frenetic growth path. War production stoked labor demand even as the military draft shrank the nation's labor supply. As the war later drew to a close, American elites accordingly worried that depression might resume. With millions of military personnel returning home, little need to continue manufacturing heavy munitions in wartime quantities, and the rest of the world too war-torn to buy American exports of any kind, the prospect of mass unemployment and renewed slump was a real one. Policy-makers accordingly moved to preempt that prospect.

Massive new infrastructure projects were undertaken at home and abroad to maintain demand for American labor and capital goods. New Deal labor laws continued to be well enforced to ensure fair - and aggregate demand bolstering wages and salaries. Millions of ex-military personnel received free higher education, which not only rendered them ultimately more productive, but also kept them more immediately out of the workforce till factories could retool for domestic not military production. And billions in aid went to war-ravaged countries, enabling them to purchase more American products.

The upshot of all of these pragmatic policy measures was a thirty-year postwar macroeconomic boom that effectively made the modern American middle class - the aforementioned 'Great Moderation.' Even as the population rapidly grew, rates of home-ownership, diploma-earning, and per capita income rose steadily. Wage and income rises matched national productivity gains year after year, and inflation was kept under wraps by a tax code whose capital gains and top marginal income rates were the highest in all of American history. Here was a case, then, in which the proverbial 'rising tide' did 'lift all boats.' It was the moderation the volatility-suppression - of that 'Great Moderation' itself that made this possible. And it was the income equalization, money modulation, and utility-style regulation that underwrote that equilibrium.

So what happened? What took us from the so-called 'Great Moderation' of 1945-75 to 2008 and today? The answer lies in a number of mutually reinforcing developments that combined to restore the immoderate economy of the 1920s to postwar America. The seeds of the trouble were sown by the Vietnam war spending of the Johnson years, which when added to Great Society spending brought both monetary inflation and social unrest. The latter developments 
ultimately brought reactionaries like Richard Nixon, Jimmy Carter, and Ronald Reagan to political power - Presidents whose attitudes toward the essential role of taxation and public institutions in 'private' economic arrangements differed markedly from those of their predecessors from Roosevelt through Johnson.

These administrations and, even more, the administrations and Congresses that followed steadily undid what the New Deal and Great Society had done. Labor legislation and its enforcement were weakened, and organized labor came both to be viewed as and to be treated as a 'public enemy.' Cross-border trade liberalization further weakened worker bargaining power. The tax code became steadily less progressive and public spending on public goods - notably critical infrastructure and education - was curtailed. All the while, deregulation of what Orwellianly began to be called 'the financial services industry' simultaneously reintroduced '20s style risk to the macro-economy while presenting policymakers with a temporarily attractive alternative to redistributive labor and tax policy cheap credit in place of real incomes to maintain growth-fueling consumer demand.

In essence, the nation moved from a regime of public provisioning of public goods and public encouragement of shared gains from growth, to a regime of publicly encouraged financial 'innovation' geared toward new forms of consumer and mortgage borrowing, by the great bulk of working Americans, from the small class of wealthy Americans and massive financial institutions. The result was an explosion of mortgage debt, consumer debt, and education debt unparalleled since the 1920s. And so, predictably, massive asset price bubble, asset price bust, and debt-deflationary aftermath struck once again.

\section{8-2018: What Have We Learned?}

What, then, are the lessons of 2008? In essence, they are the lessons of 1929 , only partly relearned. Broadly speaking, as I mentioned in introducing this essay, they are that wealth and income distribution, the credit/debt nature of money, and financial-system structure all matter, in quite critical ways, where macroeconomic stability and sustainability are concerned. 'Great moderations,' it turns out, depend critically on distributive equity, monetary stability, and macroprudential finance oversight. Let us now probe these three lessons with care.

\section{Distribution Matters:}

Most people likely agree that the distribution of power and material wellbeing in a society matter. Most, however, seem to think that it matters only as a matter of justice. They are of course right that it matters for justice. And they are right in considering justice the most important political value of all. It is critically important to be clear, however, that distributive equity bears upon economic 
efficiency and sustainability as well. Hence even reactionaries ought to concern themselves with it.

As I show in more 'scholarly' work, the reason that equity matters to financial stability and macroeconomic sustainability is straightforward. For a decentralized exchange economy to remain in full employment equilibrium - that is, in a state in which all capacity is fully utilized - what I call its 'absorptive' capacity must keep pace with its productive capacity. Its agents must be able to lay claim to - to purchase - what they produce. If they cannot, there is simply no sense in anyone's producing. And so productive activity and, with it, employment, will slow if not grind to a halt.

But an economy in which the proceeds of productive activity skew to the top of the distribution just is an economy whose absorptive capacity falls steadily further short of its productive capacity. Those at the top of a top-heavy skew cannot possibly consume all that's produced. (Your tenth yacht, we might say, is less worth your purchasing than was your ninth.) Nor can they see any reason to 'invest' in yet more productive capacity under such circumstances. And so they will 'hoard' rather than consume or invest surplus, thereby depriving the production process of its lifeblood and throwing the economy into steadily selfworsening slump.

It isn't hard to see the sense in which this state of affairs is inefficient. It is sheer waste. Productive opportunity is needlessly forgone, as are the millions of opportunities for material life-improvement that people could enjoy under conditions of full capacity utilization. For this reason, wise collective agents in any polity faced with significant wealth skews historically have acted to counteract them. The sustainable way to do that is either permanently to reroute the returns to productive human and nonhuman capital in ways that reduce income-skewing, or to 'go to the source' of income maldistribution by altering the distribution of capital itself. A more ad hoc, tenuous, and temporary way of doing so, by contrast, is to make it easier for people at the top of the distribution to lend, directly or indirectly, to those below the top - even at risk of allowing for predatory lending.

The measures we took after 1929, as described above, were measures of the first type. Such was the wisdom of the New Deal response to 1929 and the Presidents and Congresses who immediately followed. The measures we began favoring during the tax-cutting, public-sector-starving years leading to 2008, by contrast, were of the second type. And this is precisely why 2008 happened. We can see why by turning to our next 'lesson' of 1929 and 2008, which is that endogenously generated money matters just as does distribution.

\section{Money Matters:}

Money is a bit like distribution where the lessons of 1929 and 2008 are concerned: most sense that it matters, but many are not fully clear on the ways 
that it matters. We got clear and stayed clear on this for a time after 1929 , but then we forgot yet again in the lead-up to 2008.

Here is what matters about money for present purposes: as I and others have shown elsewhere, absent deliberate money-modulatory action taken by a countercyclically acting collective agent - a 'central bank' or 'monetary authority' - authorized to act in the name of all individual agents, money's supply is, as noted above, endogenous to transaction activity. Money, that is, can be issued ad libitum when speculative appetites are whetted and widespread, and can be just as severely withdrawn when market moods sour. The reason for this, in turn, is that by far the greater part of an economy's money supply takes the form of moneydenominated credit, credit that can be extended or withdrawn at a moment's notice by institutions licensed to do so by public authority - i.e., banks.

This truth about money tends to ring 'counterintuitive' to those whose intuitions have been malformed by loose talk about 'gold standards,' 'money printing,' 'financial intermediation,' and so forth. We think of money as shiny metal or green slips of paper, and of banks and other financial institutions as mere 'intermediaries' that take-in scarce capital from private depositors or investors and then reinvest it in borrowers or other end users who pay for its use. Then, continuing to think in this way, we effectively blind ourselves to the prospect that credit-money might at some times be over-issued in manners that bring hyperinflations to goods, services, or financial asset markets, and at other times be quickly withdrawn or under-issued in ways that bring crashes and slumps.

Such 'bubbles' and 'busts' are indeed possible, though, and are possible thanks to the credit/debt character and consequent endogeneity of money. You'll get a hint of the real nature of things by looking at either a standard dollar bill or a standard bank loan transaction.

Across the top of the former you will read 'Federal Reserve Note.' That's 'note' as in 'promissory note,' a written evidence of liability or obligation - that is, of debt. As for the bank loan, the bank that extends it to you needs no preaccumulated deposits to do so. It simply credits an account in your name in exchange for your promissory note when you borrow. (Loans, in other words, make deposits, rather than the other way round.) The Fed, which administers the national payments system, then 'accommodates' that newly opened or credited account by allowing payments drawn from it to 'clear.' And since those accounts are denominated in dollars as if they were stores of Federal Reserve Notes 'dollar bills' - what you're effectively doing in borrowing is temporarily swapping your own promissory note for Fed promissory notes, thereby 'monetizing' your 'creditworthiness.' For these reasons and others, I call our financial system a public-private franchise arrangement in other work, and call the bank loan 'the big swap.' 
Again, banks are publicly licensed to play this role, and have no need of deposits to do it so long as the central bank accommodates payments made from bank-credited accounts in the manner that I've just described. (Bank 'reserve requirements' are simply a form of liquidity regulation imposed by our moneymodulator or 'franchisor' - the Fed - not a functional prerequisite to bank lending.) This is precisely why nonbank financial institutions - securities firms, hedge funds, derivatives dealers, etc. - are always so keen to acquire bank charters or to affiliate with chartered banks as they did with abandon from the 1990s onward. Doing so enables them to act as issuers of that monetized public full faith and credit that is the nation's money supply, and in so doing to privatize that highly profitable 'seignorage' (in this case, rental - i.e., 'interest' - income) that money-issuers have always enjoyed. Banks and, especially, nonbank financial institutions in the US did this abundantly during the 1920s and then again in the late 1990 s and early 2000s. And that is precisely what made the bubbles and busts of both periods so massive.

As suggested above, moreover, and as shown in my more scholarly work, this capacity so heavily utilized in both boom periods dovetailed with wealth maldisribution. Most of the 'financial innovation' of both periods was about enabling people below the top of the distribution to keep consuming even while underpaid, and to afford those at the top of the distribution means of 'investing in' - that is, extracting from - those below the top of the distribution once they were too sated to consume more. (Recall that 'tenth yacht' mentioned earlier.) And because this enabled consumption and hence production and, with it, labor employment to continue, regulators looked favorably upon it. Even a benevolent Alan Greenspan, in other words, would have been tempted to go easy on credit under conditions of worsening wealth and income inequality, if for no other reason than to keep growth and employment high in conformity to the Fed's 'maximum employment' mandate.

The fact that money is endogenously generated in the way just described, and that its supply can accordingly be vastly over- or under-supplied by its publicly licensed private issuers, means that booms and busts are an ever-present danger in any decentralized exchange economy where money rather than barter is the means of exchange. And owing to the differing consumption and 'investment' capacities of rich and poor in an economy whose wealth is maldistributed, this form of fragility is especially acute in a highly unequal society. Scarce wonder, then, that the two years during which our national economy's product was most dramatically skewed were ... yep, 1928 and 2007, as I show elsewhere.

Just as we learned after 1929 that distribution matters, then, so did we learn that money matters in the way I've described. It is no accident that the nation's premier economic theorist of the 1920s and 1930s, Irving Fisher, occupied himself primarily with finance, private debt, and monetary reform after 1929. Ditto the UK's answer to Fisher, J.M. Keynes. 
The post-2008 period has seen a counterpart renewal of attention to money and finance. From neo-Fisherians through 'post-Keynesians' and Minskyites to neo-chartalist Modern Money Theorists, careful observers of how money and finance actually 'work' in a modern financial system have developed a sophisticated understanding both of the need to modulate the nation's creditmoney supply, and of when public spending and public retrenchment are accordingly called for and not. Some also have developed a related understanding of why consumer financial protection is accordingly not only a matter of fairness and honesty - though it is that - but also a matter of, again, financial stability and macroeconomic sustainability. Regrettably, as we'll see, some ignoramuses on both left and right appear to be actively working to forget this renewed understanding. But more of this presently.

The renewed understanding of money and finance post-2008 is nicely complemented by improved understanding of the remaining critical attribute of any modern financial system that I have said 'matters' - its structure. To that, then, we'll now turn.

\section{Structure Matters:}

The final lesson we learned after both 1929 and 2008 dovetails with the first two. This is that not only the financial system's component parts, but also the structure of relations among those parts, is of decisive importance where financial stability and economic health are concerned. A macroeconomy and its financial system, in short, are more than the sums of their parts. To think otherwise is to fall prey to a fallacy of composition.

Both in the lead-up to 1929 and in that to 2008, economic and financeregulatory orthodoxy had it that a financial system is simply an aggregate of the financial institutions that constitute it. This in turn would have meant that maintaining the 'safety and soundness' of each institution would effectively ensure the stability of the system as a whole. Belief in this proposition combined with belief in another - namely, that bubbles and busts are incompatible with individual rationality and market efficiency - to lead regulators and policymakers into thinking that simply prohibiting egregious fraud in specific transactions was all that was needed to maintain financial and, with it, macroeconomic health and stability. This way of thinking mistook the necessity of fraud prevention for the sufficiency of fraud prevention.

As I've shown in other work, these misconceptions proved to be misconceived in the crises of 1929 and 2008. A financial system is no more a mere aggregate of institutions than an automobile is mere heap of auto parts piled up in a parking lot. In both cases - as in the case of any 'system' as distinguished from a 'heap' - the ways in which parts function together is as important as are the parts themselves in constituting a functional whole. Likewise, bubbles and busts are no more incompatible with individual rationality and markets' informational 
efficiency than are other collective action problems - especially those I have elsewhere dubbed 'recursive collective action problems.' For market structure aggregates individually rational actions, especially those taken under uncertainty, into collectively catastrophic outcomes.

In all such situations - which include arms races, inflationary and recessionary 'spirals,' and other familiar 'tragedies' - individual rationality combined with information gaps is precisely the problem. For everyone's doing the rational thing - e.g., buying now rather than later during an inflation, laying off workers quickly to cut costs during a recession, etc. - is precisely what renders the problem, given the structure of the relevant interactions, so collectively ruinous. As I argue in earlier work on the need for macroprudential, credit-modulatory finance regulation, collective action challenges of this sort require acts of collective agency for their solution. (I call this 'regulation as modulation.') We have a name for the collective agents who act in our collective behalf - we call them organs of government.

In the wake of the 1929 crash, Congress accordingly enacted far-reaching structural and informational gap-filling reforms of the financial system. It also established new collective agents - that is, federal agencies - to enforce or otherwise act upon them. Among the latter were the FDIC and the SEC, along with the aforementioned RFC, FHA, FNMA and SBA. Among the former were disclosure rules via the Securities and Securities Exchange Acts, internal governance rules via the Investment Company Act, and of course mandatory segregation of deposittaking from speculative market trading via the Glass-Steagall Act. The upshot was a socialization of some of finance, and a deep structural reforming of the rest of finance.

By 2008, many of these post-1929 reforms had been either repealed by deregulation-obsessed politicians or effectively nullified by 'shadow banks' and 'conservative' judges. During the years over which this happened, moreover, influential pundits, academics, and even some central bankers had revived the old misconceptions that systems are mere sums of their parts and that financial dysfunction cannot coexist with individual rationality and market informational efficiency. They lost sight, in other words, of how the structure of our financial system underwrites massive collective action problems under conditions of uncertainty. In the wake of the most recent crash it was accordingly necessary once more to impose structural reforms upon finance and its regulation, on the one hand, and to reeducate pundits and regulators about the need to regulate finance in bubble-preemptive rather than -reactive fashion on the other hand.

This renewal of the wisdom of the 1930s came primarily in the form of the Dodd-Frank Act on the one hand, and a burgeoning academic and regulatory literature offered by myself and others on 'macroprudential' regulation on the other hand. For a time, we regained at least some appreciation of former Fed Chair Bill Martin's adage that the Fed can and should 'lean against the wind' - i.e., act 
countercyclically - and rejected later Fed Chair Alan Greenspan's claim that the better course is to let bubbles bubble and burst and then 'clean it up afterwards.' The 'leaners' again carried the day, while the 'cleaners' skulked back to their think tanks. By the same token, we relearned the lesson that consumer financial protection can be as much about system stability as it is about basic fairness.

The trouble, however, is that these gains were more modest post-2008 than they had been post-2009 - and are already now being reversed. Though there was talk of a federal takeover of banking, that never happened - only FNMA was returned (for the time being) to federal conservatorship. And while there also was talk of renewing Glass-Steagall, all we got was a weak cousin now known as 'the Volcker Rule.' And now we find both Republicans and, to a lesser extent, Clintonite Democrats already scaling back Dodd-Frank's reforms. This takes us on to my final set of observations, those concerning what we must do.

\section{8 and Beyond: What, Then, to Do?}

For reasons I've hinted at and will elaborate more fully now, I consider our response to the 2008 crash to have been inferior to those we pursued in response to the ' 29 crash. It is also the case, as just noted, that even the little we did is already being rolled back. In considering what to push now, ten years on, then, I suggest that we look to the New Deal example and push even further, in a manner resistant to backsliding of the kind that commenced in the late 1970s and, now, late 2010s. I'll structure my suggestions along the lines of the three 'lessons' elaborated above - that wealth and income distribution, endogenous money, and finance system structure all 'matter.'

Beginning with distribution, as noted earlier tax law, labor law, and public investment in educational and other infrastructures were all critical during the New Deal era and during the three or four decades that followed. These all helped ensure a distribution of the gains to economic growth that was not only more just, but also more stabilizing, thereby maintaining that growth and continuing prosperity itself. Nothing so much as approaching these measures in either duration or magnitude has followed the 2008 crash. Such stimulus spending as there was was both brief and quite small in relation to GDP. Labor rights and bargaining power, meanwhile, have continued their decline. And tax policy has continued to be all about cuts for the wealthy, which has both exacerbated our inequality problem and furnished 'austerian' politicians with further excuses to slash stimulative and poor-assisting public spending. (At the time of this writing, they are already at it again.)

The upshot of all of this is that inequality has if anything worsened since 2008, particularly when we take slashed social services into account. And one outgrowth of this, in turn, has been a resurgence of growth in private debt among those below the top of the national wealth and income distributions. Now we must worry not only about mortgage debt, but also about student debt, credit card debt, 
and other forms of consumer debt, all of which are quickly surpassing their previous records. And all the while, critical public infrastructure continues to crumble, leaving the nation more and more like an 'underdeveloped' country as diminished public spending imposes further costs upon private enterprise.

In the long term we are going to have to reckon with all of this, for all of the reasons adduced earlier. How do we do that?

This isn't rocket science. Labor rights and union power must be buttressed again, through legislation like that passed during the New Deal. Unionization must also be brought into new industries that both lack it and now account for a larger share of the labor force than ever before. Minimum wage laws must be updated as well - and, for the first time in our history we should begin a serious job guarantee program. That will not only bring work to the still unemployed, but also enable our polity to change prevailing wage rates flexibly, rather than only infrequently jacking up minimum wages and risking periodic disemployment in the process.

Tax policy, for its part, must be made more progressive again, at least if and when rising wages and employment bring inflationary pressures back to goods, services, or asset markets. This, after all, is the actual purpose of tax policy - to take money out of over-endowed sectors of the economy when money spent into other sectors begins to raise prices once all capacity is once again utilized. Since by far the greater part of inflationary spending takes place in secondary financial and derivatives markets rather than goods markets now, moreover, the taxes to raise once we raise should be the estate and capital gains taxes, accompanied if necessary by a new financial transactions - a.k.a. 'Tobin' - tax. Here too, we see, the distributively just policy will also be the efficient policy.

In addition to these measures, which bear most directly on income inequality, at least two additional ones, aimed more at wealth inequality, will have to be taken. First, on the liability side of household balance sheets, significant debt write-downs will likely be necessary, particularly in connection with student debt. At $\$ 1.6$ trillion and rising, this is now the second highest private debt category in the nation. As work I've done elsewhere now demonstrates, it is delaying young Americans in family formation, home buying, and small business starting. Most of the delinquent such debt, moreover, was incurred in pursuit of educations from for-profit entities like Trump 'University,' whose degrees are now proving worthless where job-attainment is concerned. Against this backdrop, debt forgiveness looks to be as just as it will be stimulative and efficient. Meanwhile, we must return to the education finance policies that prevailed till the late 1980s, whereby high quality higher education could be attained without the incurring of crushing debt. 'Debt-free education,' which is becoming a watchword, should be made now to name a reality.

On the asset side of household balance sheets, we must both return to the federal mortgage finance policies that prevailed prior to the 1990s, when home- 
buying was kept free of private sector predation and all Americans with living wage jobs could buy homes and become responsible stakeholders in their communities. Going beyond homes, we must begin taking measures that make business capital owners of all Americans. It is well documented, including in earlier work of my own, both that returns to capital far exceed returns to labor over time, and that capital ownership is concentrated in the top $10 \%$ of the national wealth distribution.

Both in some of my scholarly work and in a forthcoming book, I show how to spread capital ownership far more widely, in ways that will not be experienced by the presently wealthy as 'confiscatory.' (We can, in short, 'level up' rather than 'leveling down.') One attractive way to start is by conditioning free trade agreements on benefitting firms' issuance of shares to 'outsourced' employees. Another is to assist employees in buying out (or buying shares in) employing firms. There will be much more to say on these matters in future.

Turning from what we now know about distribution to what we now know about money, we must reconceive and reconfigure the way we do public and private investment in light of improved understanding about money and finance. On the public side, there is simply no reason for the public not to spend all that is needed on critical infrastructure, education, health, and a full federal job guarantee. Because money is endogenously generated in effect by the central bank as described above, the only spending constraint is what neo-Fisherians, postKeynesians and Modern Money Theorists all call the 'resource constraint.'

In effect, that means that public money can be 'spent into existence' quite freely until capacity constraints are met, after which money must be compensatingly taken out of the economy to avoid generating inflationary pressure. One way to do that, as noted above, is via taxation where overspending is most dramatic - viz., again, by wealthy individuals and large financial institutions in the secondary and derivatives markets.

Taxing the wealthy whose 'investment' behavior stokes asset price hyperinflations - a.k.a. 'bubbles' - is an obvious place to begin. Those inflations are the best indicator out there that 'investments' of this sort afford no lasting benefit to the 'real' economy, but only exacerbate wealth inequalities, private debt buildup among the non-wealthy, and destructive boom and bust cycles. I'll say more on this presently when I turn to finance system structure.

Another way to siphon money away from unproductive bubble-inflating financial speculation once the economy reaches full capacity is to revive the aforementioned New Deal era RFC in contemporary form. In other work I have proposed a 'National Investment Authority,' or 'NIA,' which like the RFC would be publicly run and in part privately financed. 
The Authority would overcome the collective action and macro-control challenges that prevent private institutions from investing adequately in public goods, thereby rectifying the private financial sector's most wasteful misallocation problems - problems that result in far too much credit-money's flowing to secondary financial markets that 'invest' not in new product or productive capacity, but in already-issued financial instruments. At the same time it would offer a means additional to taxation for soaking up excess money once public spending restored the economy to full capacity utilization - all while offering investors reasonable returns on real investments instead of mere gambles on price movements in secondary markets.

A final reform I believe will be well advised in light of what we now know about money is to begin what I elsewhere propose under the rubric of what I call 'Citizen Central Banking.' It is now technologically feasible for the Fed to maintain what I call 'Citizen Accounts' for every citizen. There is no reason not to do so, and every reason to begin doing so at once.

Doing this will offer two immediate benefits. First, it will yield every American access to savings, payment, and related banking services, without having to subject themselves to the pervasive indignities and forms of exploitation to which private banking institutions continually subject them. And second, it will afford the Fed means of conducting monetary policy far more efficiently and effectively than it does now. When stimulus is needed, for example, the Fed can simply credit citizen accounts directly, and in debt-free fashion, rather than pumping money to Wall Street dealer banks via open market operations and hoping they'll lend some to citizens rather than betting it on commodity price movements. (A form of 'QE for the People.') And when contractionary pressure is needed, the Fed can simply offer higher interest on citizen holdings, thereby incenting more saving.

All of these far reaching reforms show themselves to be feasible when we grow clear both about history and about the endogenous character of money. Progressives must avoid, at all costs, the benighted and self-crippling nostrums of economic orthodoxy as enunciated by complacent reactionaries and lazy selfstyled leftists alike. No thoughtful progressive says public money can be spent without limit, nor does any thoughtful 'conservative' believe austerity to be truly necessary. What all clear-eyed people see is that money can be issued and spent without worry - and without prior 'raising' or pre-accumulation - until full productive capacity is reached, and that thereafter all excess money can be impounded in any number of ways, be it taxation of the kind noted above, sales of public investment securities like the NIA issuances noted above, or paying interest on unspent Fed Citizen Account savings as proposed above.

These last observations take me to my final set of recommendations - those rooted in appreciation that financial system structure matters. One way of looking at the National Investment Authority and Citizens' Fed proposals just mentioned is 
as additional tools for macroprudential finance regulation of the sort I discussed earlier in connection with system structure. They are, after all, money-modulatory institutions that can inject financing into the economy during slowdowns, and remove money from circulation during boom phases - thereby acting countercyclically in the way that I said is the hallmark of macroprudential finance oversight. But these institutions, along with additional measures, can also help restructure our financial system in ways that correct for its endemic tendencies to misallocate funds.

The NIA can do this in a manner that I suggested above: it can attract money from investors and then deploy it, instead of toward speculative activity in secondary and derivatives markets, toward productive activity in primary markets or infrastructure. Private investors and institutions lack control over the macroenvironment on whose stability the profitability of many primary market investments depends. They also lack taxing authority of the kind that enables recoupment of uncapturable gains from public investment. Our ultimate collective agent - our government - suffers neither of these collective action infirmities, and can accordingly afford incentives to 'private' investment in 'public' goods that no private institution can muster. That is a textbook case of correcting misallocation rooted in 'market failure.'

A Citizens' Fed of the kind I just noted could act similarly, by targeting different accounts differently for capital injection or capital impoundment, depending on which sectors of the economy at a given time are receiving inadequate capital, and which receiving too much. Coordinating with the NIA, much as the Fed itself used to do with the RFC, it would in time prove an optimal maco-allocator of real investment capital, thereby shrinking the inherently destabilizing and destructive quantum of merely speculative capital.

Complementing these institutional measures, however, I think will have to be two additional reforms, both with New Deal predecessors. The first is to restore the Consumer Financial Protection Bureau ('CFPB') to full functionality - that is, to that which it had before Mr. Trump unlawfully installed his personal employee, Mr. Mulvaney, at its helm this time last year. While at it, we must afford it full jurisdiction over the auto loan and payday loan industries, notwithstanding the efforts of ersatz progressives like Rep. Wasserman-Schultz to keep such exploitative industries insulated. The reason, as noted above, is that these practices not only work unconscionable injustice, but also act as conduits of systemic risk, via the buildup of bad debt and worsening inequality, into the financial system. That was of course how nonprime mortgage loans acted in the early years of the millennium, and how counterpart products acted during the 'roaring' - i.e., bubbling - '20s.

The second additional structural reform we should consider is a contemporary counterpart to the New Deal's Glass-Steagall segregation noted above. This will not, however, be simply about 'separating commercial from 
investment banking' as it was in the past. For what Glass-Steagall was really about was insulating primary market investment from dependence on speculative secondary market gambling institutions. That functional separation used to be more or less workable via the institutional separation of commercial from investment banking because institutional form used to follow function. Since the repeal of bank branching and affiliating restrictions in the late 1990s, however, our largest financial institutions are conglomerate in structure and combine most functions - primary, secondary, and tertiary ('derivative') alike - 'under single roofs.' That means we must 'return to square one' where restoring Glass-Steagall's concerned.

How to do that? The key distinction, as noted before, is that between primary market investment and secondary/derivative market speculation. Allowing the latter can of course aid the former by lowering liquidity risk and other risks that can threaten the former, thereby lowering the cost of privately afforded capital. But this doesn't mean we must allow those who facilitate primary market investment and those who facilitate secondary and tertiary market trading to affiliate and operate 'under the same roofs.' Indeed, allowing that is a recipe for conflicts of interest and associated buildups of systemic risk. It is also quite clearly unnecessary for purposes of lowering capital cost once we realize, as the endogenous character of money makes plain, that finance capital is anything but 'scarce.'

In other work I accordingly map out a comprehensive Glass-Steagall-like structural reform that doesn't simply separate deposit-taking from capital market institutions - a separation that the above-described Citizens' Fed will largely bring about anyway - but also separates capital market institutions themselves into distinct capital-raising (primary market) and capital-trading (secondary and tertiary market) institutions. This, I suspect, will be necessary, if not of itself quite sufficient, to prevent speculator losses on secondary and derivatives markets from bankrupting capital-users on primary markets. Combine this with the NIA's and Citizens' Fed's siphoning excess capital away from secondary and tertiary markets, and with both institutions's capacities endogenously to inject needed capital or liquidity in the event of market stress, and you have the closest thing to a riskproof, panic-proof, misallocation-proof, and mismodulation-proof financial system that we've ever known.

\section{Conclusion}

I've covered a good bit of ground here, but I fear that the subject requires it. The crisis of ' 08 stemmed from multiple rectifiable vulnerabilities. Understanding and responding to it requires full consideration both of those vulnerabilities and of the means by which they can be addressed. Happily, however, we have been here before, and have precedent from which to learn in the matters both of diagnosing the ills and designing the cures. I've tried to aid understanding of both ills and cures by grouping them under the key headings of distribution, money, and 
systemic structure, and by referring back to our present situation's antecedents in the New Deal era and after. I hope that has rendered things reasonably tractable.

Complex as it all might seem, things are actually simple enough here to warrant both optimism and determination. The tripartite proverbial bottom line is (1) that financial and economic disequilibrium are ultimately rooted in wealth and income inequality, (2) that those ills are curable through wise deployment of what's ultimately our endogenously generated money, and (3) that that wise deployment can be straightforwardly assured by a few simple institutional and structural reforms of the kinds sketched above. We have done these things before. There is no reason that we cannot do them again - and do them yet better and enduringly this time than last time. 